\title{
The Effect of MCSQ and COSE on Customer Loyalty Through Customer Satisfaction in Private Hospital in Surakarta
}

\author{
Sri Isfantin Puji Lestari \\ STIE Wijaya Mulya \\ isfantin63@yahoo.com
}

\author{
Retnoning Ambarwati \\ STIE Wijaya Mulya \\ retnoningambarwati1972@gmail.com
}

\begin{abstract}
The purpose of this study is to analyze the influence of Customer Orientation of Service Employees (COSE) and Management Commitment of Service Quality (MCSQ) on customer satisfaction as well as its impact on customer loyalty to Hospitals in Surakarta. The result of this study shows that the COSE and MCSQ have influence on customer satisfaction and customer loyalty. In conclusion, customer satisfaction is an intervening variable that can mediate the effect of variable COSE and MCSQ on customer loyalty.
\end{abstract}

Keywords: COSE, MCSQ, Customer Satisfaction, and Customer Loyalty

\section{INTRODUCTION}

Hospital is one of the health facilities that control an important role in the fulfillment of the public health's right. Various medical technologies and the latest concepts thrive as information technology advances. Issues on productivity, quality development, and even distribution of services are the world's key hospitals [1]. Hospital preparedness in providing health services is demanded as changes occur. Prominent features are competitive traits that serve as the basis for the development of hospital service quality. Without the competitive nature of hospitals in Indonesia, it will be difficult to adhere to overseas services. Output from hospitals is a product of healthcare services, so the main principle that must be held in marketing healthcare products is to build and maintain customertrust. In the midst of intense hospital competition, it is important for hospital management to be more professional in managing the hospital in order to survive and develop. Therefore, the hospital needs to know the satisfaction of the patients.

The atisfaction as: "a person's feelings of pleasure or dissappointment resulting from comparing a product's perceived performance (or outcome) in relation to his or her expectations" [2]. In hospital services, a patient is said to be satisfied if the service performance matches or exceeds the patient's expectation, as Hu's opinion, [3] "if the performance matches or axceeds the expectations, then the customer is satisfied, if performance is below par then the customer is satisfied, if performance is below par then the customer is dissatisfied". Quality services manifested by service performance are determined by the service delivery behavior of doctors, nurses, medical personnel and administration. This is because the behavior of service delivery plays an important role in shaping the patient's perceptions of service [4].

In the context of hospital services, service delivery is the last person to carry out hospital marketing efforts and the first person to directly interact with customer. In other words, employees are required to have an orientation on customer' needs or customer orientation of service employees (COSE). [5] COSE is defined as the behavior of service employees when serving the needs and wishes of existing and prospect customer.The employees' behavior which is customer oriented is supported by management's commitment to service quality so as to produce an optimal service performance, as Babakus [6] points out that management commitment to service quality (MCSQ) is a critical determinant of employees' behavior in creating service excellence meaning that MCSQ is an important determinant in creating an excellent service. According to [7] supportive management characterizes management concerns and support for employees' work and represents the degree to which they create a facilitative climate of support, trust and helpfulness.

Based on the above statements, it can be concluded that employees' behavior as a manifestation of COSE and management commitment to quality service (MCSQ) as a service provider is something that is important to affect the service performance, and the performance of the resulting service will provide customer satisfaction. Thus, it implicatescustomer loyalty, since the interaction between service providers (hospitals) and patients is sustained. It means it does not end after the treatment is completed, but it will continue as patients' re-control in the outpatient poly, at the time of the patients' subsequent examination and treatment. This is because the patient's medical record data placed in the hospital become a guide and referral examination and treatment so that the treatment of patients can take place comprehensively.

\section{METHOD}

This research is explanatory research. Explanatory research is intended to obtain clarity or explain phenomena and relationships and to test the influence of variables (including the cause of the relationship) [8]. This research uses four variables: MCSQ, COSE, customer satisfaction, and customer loyalty in exploring the variable that uses survey in the form of expressing opinion on some statement items (indicator that is answered by the outpatient who has been hospitalized at private hospitals in Surakarta. 
Data analysis technique used to discuss the problem in this research is Structural Equation Model (SEM). The Structural Equation Model (SEM) is a statistical technique that allows testing of a relatively complex set of relationships simultaneously. Complex relationships can be built between one or more dependent variables with one or more independent variables. There may also be a variable that doubles as an independent variable in a relationship, but becomes a dependent variable on other relationships considering the existence of a tiered causality relationship.

\section{RESULT}

Structural Equation Model (SEM) analysis has several stages, prior to modeling, some tests such as validity test and reliability test, SEM assumption test, and analysis of SEM test result. Based on the test results, it is noted that all correlation coefficients have a value greater than $r$ table $(0.361)$, so it can be concluded that all statement items on each variable are valid and can be used for further testing. The reliability test is used to test the extent to which the gauge is relatively consistent when the measurement is repeated two or more times. The reliability of test results are known that all Cronbach's Alpha values are greater than 0.6. It can be concluded that it is reliable, meaning that each item of statement submitted for each variable is feasible to be used in further analysis.

Figure 1. The results of the evaluation of the Goodness of Fit Indices criteria

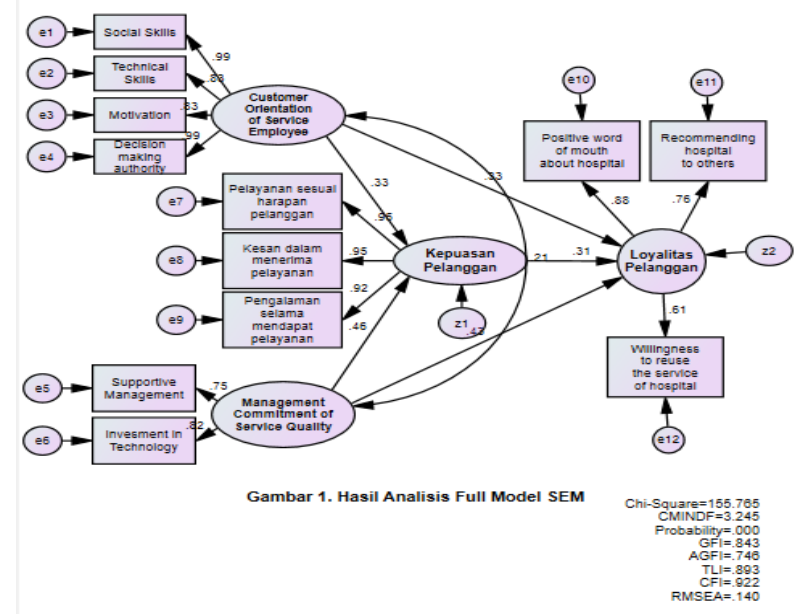

The results of the evaluation of the Goodness of Fit Indices criteria in Figure. 1 show that the evaluation of the overall model as satisfied, and then the model is acceptable.

In explaining the effect of exogenous variables on endogenous variables, structural equations are used. Coefficient results can be seen in table 1 as follows:

Based on the results of hypothesis testing, it is shown that the probability value generated by all variables have error rate $\leq 5 \%$. This shows that COSE and MCSQ have a significant effect on customer satisfaction and loyalty, customer satisfaction has a significant effect on customer loyalty, and COSE and MCSQ have an effect on loyalty through customer satisfaction in this case, the patients in private hospitals in Surakarta City.

Table 1. Hypothesis Testing Results

\begin{tabular}{lll}
\hline \multicolumn{1}{c}{$\begin{array}{c}\text { Endogenous } \\
\text { Variable }\end{array}$} & $\begin{array}{l}\text { Exogenous } \\
\text { Variable }\end{array}$ & $\beta$ \\
\hline $\begin{array}{l}\text { Customer } \\
\text { Satisfaction } \\
\left(Y_{1}\right)\end{array}$ & $\operatorname{COSE}\left(\mathrm{X}_{1}\right)$ & 0,332 \\
$\begin{array}{l}\text { Customer } \\
\text { Loyality }\left(Y_{2}\right)\end{array}$ & $\operatorname{MCSQ}\left(\mathrm{X}_{2}\right)$ & 0,457 \\
& $\mathrm{COSE}\left(\mathrm{X}_{1}\right)$ & 0,328 \\
& $\mathrm{MCSQ}\left(\mathrm{X}_{2}\right)$ & 0,426 \\
& $\begin{array}{l}\text { Customer } \\
\text { Satisfaction } \\
\left(\mathrm{Y}_{1}\right)\end{array}$ & 0,310 \\
\hline
\end{tabular}

COSE and MCSQ have an effect on customer satisfaction, in this case, patients at private hospitals in Surakarta. This shows that the patients are satisfied with private hospitals in Surakarta because the service is considered being able to meet the expectations of the patients in private hospitals in Surakarta. Not only the patients' expectations are fulfilled, but also the quality of the always-awake service makes the patients impressed by the experience while receiving service from the hospitals.

COSE affects patient loyalty. It shows that doctors, nurses and employees with technical and social skills are able to motivate patients and make decisions that can increase patient loyalty. It is therefore necessary technical, social, motivational and decision-making skills to perform patient-oriented performance [7]

MCSQ affects patient loyalty. Itindicates that patientloyalty will arise if the implementation of MCSQ quality provides quality services in terms of management support and technology investment. MCSQ must be constant and should reflect that commitment in the implementation, because patient loyalty is very important for the hospital, for the continuity or the existence of private hospitals in Surakarta. Baloglu [9] states that customer loyalty means customer may repeatedly purchase a product or service, or exhibit "behavioral loyalty for reasons other than an attitudinal commitment to the brand or company. The result of this research is consistent with [10].

This research findings suggest that MCSQ is more dominant in affecting patient loyalty than COSE. This means that from the customer side, to increase customer loyalty, it requires more commitment and management support on the quality of service compared to the behavior of officers oriented to customer needs. MCSQ especially formed by the commitment of management in maintaining the quality of services in the hospital will perceive that patients are able to meet the needs and needs directly. Therefore, if the quality of service to patients is always maintained, then it is able to motivate patients to increase their loyalty so that patients will say positive things about the hospital, recommend the hospital to others, and are willing to go back to the hospital. 
The patient satisfaction in private hospitals in Surakarta is formed from the indicators of services that meet the expectations of patients, the impressions in receiving service and satisfaction experience during the service. If the indicator is in accordance with patient expectations, especially services in accordance with patient expectations, then it will increase patient loyalty to private hospitals in Surakarta. Loyal patients will say positive things about the hospital, recommend the hospital to others, and are willing to go back to the hospital. As Oliver [12] points out loyalty as: "A deeply held commitment to rebuy or patronize a preferred product / service is consistent in the future, there are causing purchasing situational influences and marketing efforts having (1) positve word of mouth about hospital, (2) recommending hospital to others and (3) willingness to reuse the services of hospital (Rashidian et) This is in line with[11] opinion that the relationship between loyalty and satisfaction is when the consumer reaches the highest level of satisfaction that creates strong emotional ties and commitment with the company's service.

Therefore, private hospitals in Surakarta as service provider must always follow the development of patient expectations. It should be done so that the hospitals can fulfill what is expected by the patients to satisfy the customer. Customer satisfaction is something that can not be dissolved in any service or service, because customer satisfaction will make the hospital more advanced and appreciated. If the hospitals can providepatients with satisfaction, they can make patients feel their needs can be fulfilled by their home in terms of health. [12]

The research findings indicate that customer satisfaction,especially those formed by the experience of satisfaction during healthcare, is a dominant indicator affecting customer loyalty.

An important finding in this study is that customer satisfaction, especially those formed by the experience of satisfaction during healthcare, may be a mediator of COSE and MCSQ on patient loyalty in private hospitals in Surakarta. Quality service that is maintained and oriented to the needs and expectations of customer in this case is the patients at private hospitals in Surakarta. It will lead to a deeper awareness of the customer to be willing to go back to the private hospitals in Surakarta and recommend to others when the patients are satisfied with the private hospitals in Surakarta.

\section{CONCLUSION}

Private hospitals' customer loyalty in Surakarta can be obtained by providing quality and satisfactory services supported by a commitment of the hospital management for providing quality and services oriented to customer, in this case, hospital patients. A quality management commitment and a healthcare provider are capable of dealing with patients that will result in service performance that has an impact on increasing patientsatisfaction with the hospitals. Patient satisfaction will ultimately also affect patient loyalty to private hospitals in Surakarta.

\section{REFERENCES}

[1] Hennig-Thurau dan Thorsten, C. "Customer Orientation of Service Employees - Toward a Conceptual Framework of a Key Relationship Marketing Construct". Journal of Relationship Marketing. 2003.

[2] Hennig-Thurau dan Thorsten. "Customer Orientation of Service Employees. Its Impact on Customer Satisfaction, Commitment, and Retention". International Journal of Service Industry Management. 2004.

[3] Hu, H. Kandampully, \& Juwaheer, T.D. "Relationship and Impacts of Service Quality, Perceived Value, Customer Satisfaction, and Image: An Empirical Study”. Service Industries Journal. 2009.

[4] Kotler, P. "Marketing Management”. International Edition. Prentice Hall. Singapore.2003.

[5] Po-Young, et al,."Service Quality, Customer Satisfaction, Customer Trust, And Loyalty in an EBanking Context". Society for Personality Research. 2012.

[6] Trinastoro, L. "Aspek Strategis Manajemen Rumah Sakit”. Yogyakarta: Andi. 2005.

[7] Ashill, N.J, et al,. "The Effect of Management Commitment to Service Quality on Frontline Employees' Affective and Performance Outcomes: An Empirical Investigation of the Newzealand Public Healthcare Sector”. Journal of Strategic Marketing. 2008.

[8] Babakus, E. et al,. "The Effect of Management Commitment to Service Quality on Employees' Affective and Performance Outcomes". Journal of the Academy of Marketing Science. 2003.

[9] Ulfatin, N. "Metode Penelitian Kualitatif di Bidang Pendidikan: Teori dan Aplikasinya". Malang. 2014.

[10] Tjahyono, R. "Implikasi Dimensi COSE dan MCSQ Terhadap Kepuasan dan Loyalitas Pelanggan di RSI Sultan Agung Semarang. Malang. 2012.

[11] Baloglu, Seymus. "Demensions of Customer Loyalty: Separating Friends From Well Wishers". Cornel Hotel and Restaurant Administration Quarterley. 2002.

[12] Oliver, R.L. "Satisfaction: A Behavioral Perspective on The Consumer”, New York: McGraw Hill. 1997.

[13] Rashidian, G.T, "The Effect of Service Quality on Patient loyalty: a Study of Private Hosptal in Tehran, Iran”. Iranian of Journal Public Health, 2012. 